\title{
Leadership and Post-Conflict State Rebuilding: Iraq after 2003
}

\section{Case Study}

\section{Liderazgo y reconstrucción del Estado en el Posconflicto: Irak después del 2003}

\author{
Inass Abdulsada Ali** \\ University of Baghdad, Iraq-Baghdad \\ http://orcid.org/0000-0002-6840-1500 \\ Sana Kadhim Qati*** \\ University of Baghdad, Iraq-Baghdad \\ http://orcid.org/0000-0001-5241-9397 \\ Batool Hussain Alwan **** \\ University of Baghdad, Iraq-Baghdad \\ https://orcid.org/0000-0002-9674-536x
}

Artículo de investigación

Fecha de recepción: 21 de febrero de 2020 Fecha de aceptación: 20 de abril de 2020

* This article was presented at an academic event, and will be published in Arabic in the Arab Journal for Scientific Publishing.

** Assistant Professor of International Studies, College of Political Science/University of Baghdad, Iraq-Baghdad. Academic and research specialization: International Relations Theory; Peace and Conflict Studies. E-mail: inass3a@copolicy.uobaghdad.edu.iq

*** Assistant Professor of Political Thought, College of Political Science/University of Baghdad, Iraq-Baghdad, Department of Political Thought. Research: political thought and peace and Conflict Studies, in addition to Gender Studies. E-mail: sanaa.kadem@copolicy.uobaghdad.edu.iq

**** Assistant Professor of Political Thought, College of Political Science/University of Baghdad, Iraq-Baghdad, Academic specialization: Political Thought. E-mail: batuol.hussin@copolicy.uobaghdad.edu.iq 


\title{
Para citar este artículo:
}

Ali, I. A., Qati, S. K., y Alwan, B. H. (2020). Leadership and Post-Conflict State Rebuilding: Iraq after 2003 Case Study. Campos en Ciencias Sociales, 8(2), 347-368. DOI: https://doi.org/10.15332/25006681/6022

\begin{abstract}
The Iraqi political and social arena has been characterized, subjectively and objectively, by the weakness of leadership building. This has led to a leadership crisis, which is reflected in the quality of the outcome of the process of rebuilding the state in Iraq. Thus, this building process has lacked the simplest requirements and conditions of success. It has suffered from a major and obvious failure: the situation in Iraq has raised conflict leaders, not constructive leaders, and this confirms the existence of a cultural crisis in the production of conscious, aware leadership compatible with democratic action. The weakness of leadership in Iraq is reflected in a series of ongoing crises that require radical solutions in accordance with longterm strategic plans; the crises are especially reflected in the absence of constructive visions and the predominance of self-interest, along with the impact of social reality on leadership practices, which has an adverse effect on state-building.
\end{abstract}

Keywords: leadership, state-building, rebuilding state, Iraq, leadership crisis.

\section{RESUMEN}

El escenario político y social iraquí se ha caracterizado, subjetiva y objetivamente, por la debilidad de la construcción de liderazgo. Esto ha dado lugar a una crisis de liderazgo, visible en la calidad de los resultados del proceso de reconstrucción del Estado en el Iraq, que ha carecido de los requisitos y condiciones de éxito más simples. Este proceso sufrió de una falencia importante y obvia: la situación en Irak ha generado líderes para el conflicto, no líderes para la construcción, y esto confirma la existencia de una crisis cultural en la producción de un liderazgo consciente y compatible con la acción democrática. La debilidad 
de los dirigentes de Iraq se refleja en una serie de crisis continuas que requieren soluciones radicales de conformidad con los planes estratégicos a largo plazo; las crisis se reflejan especialmente en la ausencia de visiones constructivas y el predominio del interés propio, junto con el impacto de la realidad social en las prácticas de liderazgo, lo cual conlleva un efecto adverso en la construcción del Estado.

Palabras clave: liderazgo, construcción del estado, reconstrucción del estado, Irak, crisis de liderazgo.

\section{INTRODUCTION}

Leadership, as an organizational behavioral pattern, is a necessity within the human group. Coexistence requires a high level of administrative organization in order to manage relationships and meet needs. As long as leadership has a direct impact on all different fields and at all levels, negative results within these fields and levels are related to leadership crisis, especially to the absence of leaders with clear visions to change reality for the better and the proliferation of leaders who cause ongoing crises while strengthening narrow affiliations at the expense of a sense of belonging to the homeland and thus reduce the chances to build the homeland in light of different visions and objectives and multiple interests and engagements.

Therefore, studying the issue of leadership and its important role in rebuilding failed or post-conflict states is an important starting point to know what the absence of strong and effective leadership means.

A large number of studies and research papers have been written on the subject of state-building, and according to the expression of Chesterman (2011, p. 3), "the literature on state-building is immense now" due to the vague definition given to the concept under discussion. Perhaps the most prominent of these texts is Fukuyama's book (2004) which deals with the process of state-building as one of the most important issues of society, given that weak or failed states remain the source of many serious problems in the world. Fukuyama discussed the Iraqi and 
Afghan models in his book. Ogun and Aslan's study (2013) is based on the same idea, namely, that the failure of states poses a major threat to world order, and so state-building processes are necessary to promote it.

Iraq was also presented in the previous report by Dobbins et al. (2003), published by RAND. The goal of this report was to analyze and extract the best practices in post-conflict nation-building from the post-World War II experiences of the United States and to identify the key determinants of the success of those operations. The report included seven case studies: Germany, Japan, Somalia, Haiti, Bosnia, Kosovo, and Afghanistan. The final chapter examined the challenge ahead of building a democratic, economically vibrant Iraq and recommended best-practices policies for achieving these goals based on the lessons learned from the case studies.

There are also Arabic studies on this subject, most notably that of Farhat (2015), which examines the experiences of occupying states, especially the United States, in rebuilding the countries that they occupied, regardless of whether the result was a failure or a success. Meanwhile, Hussain's study (2015) links political leadership and the reconstruction of the state. The author gives the process an internal dimension, rather than an external one, by focusing on the influential role of political leadership in this process, and chooses president Putin as a model for this type of leadership, given the impact of his visions and goals in the process of nationbuilding/reconstruction in Russia.

Concerning Iraq, we have looked into Bouillon's research (2012) in which the author discusses the need to consider the historical importance of the long-term weakness of the Iraqi state in attempting to advance and consolidate the current state-building process in the country. Relying on conceptual literature concerning the fragility and failure of the state, the author explains the extent to which Iraq requires to build the state in theory as well as in practice.

When considering leadership, we are not just focusing on political leadership, but on all types of leadership, nor do we mean the person of the leader. As far as we try to prove that leadership is an act of relationship and a value of practice, we propound 
that it is a code of conduct, which we will study from the perspective of behavior and the ability to apply it. Behavior determines the political life of a society, while the ability to apply a code of conduct charts the direction of this society. De Tocqueville considered behavior, which he defined as the outcome of the moral and intellectual inclinations of people in society, "as the most important influence in maintaining American political institutions". Behaviors are more important than laws or natural conditions (Mottahedeh, 2001).

The Iraqi political reality after 2003 provides a clear example of this fact. The Iraqi political process has suffered from a lack of subjective and objective leadership structures, and this has generated a leadership crisis, which is reflected on the quality of the process of rebuilding the state in Iraq; this process lacked the most basic requirements and conditions of success, as it suffered from a clear confusion due to the leadership crisis.

The core of our research is tracing the relationship between the leadership and the process of rebuilding the state in Iraq after the overthrow of Saddam Hussein's regime. In light of the great importance of this relationship, especially in countries experiencing internal conflict or emerging from internal conflict, it can be said that one of the main causes of the collapse of state institutions is poor power-sharing and resource allocation.

\section{LEADERSHIP IN THE IRAQI CONTEXT}

Leadership is one of the most important concepts addressed in social, psychological, behavioral, and political sciences. However, despite nearly a century of academic research, there has been no agreement on its basic meaning, as well as on the possibility of identifying, measuring, or predicting its effects; this may not be due to lack of interest in this subject or lack of relevant material, as thousands of books have been written about it. As Grint (2010) says, the key element in defining leadership is not in creating a system of terms for it, because we do not need to agree on a definition as much as to know what definitions are. 
In the field of political science, the word leadership was not to be found in the index of any political text before Glenn D. Paige's work, "The Scientific Study of Political Leadership", which appeared in 1977. In a computerized index of keywords for 2,614 articles published between 1906 and 1963, the word "leader" appeared only seventeen times, but ever since Paige expounded on the fateful role of leadership in shaping political events, scientists have realized its importance. In 1980, in his collected lectures, entitled Politics as Leadership, Paul Anthony Brick stated that Robert Tucker described leadership as the core element of politics and he himself saw leadership as the core of politics (Post, 2004).

Grint (2010) develops a quadrant classification (Figure 1) according to the perspectives from which leadership may be analyzed. Grint claims that this classification does not cover all aspects of leadership, but a large part of it. He also claims that it is not a hierarchical classification, so none of its elements is more important than any other, but each of them is based on foundations that may be conflicting. Leadership may be understood as the personality of the leader, or in terms of the occupational position of the leader, or defined as a process that describes how leaders adopt it, or, finally, classified according to the results approach, which limits the idea of leadership simply to moving a group or community to achieve a certain purpose.

Figure 1. Quadrant Classification of Leadership

\section{Leadership as:}

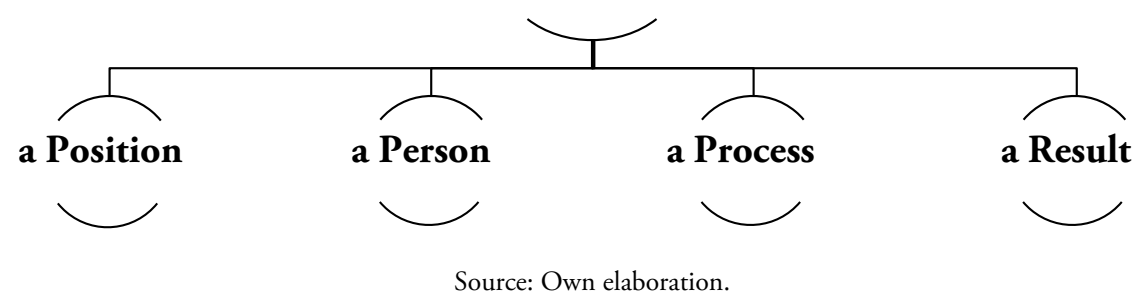

The four categories are to be situated within the context of the leadership process; good leadership is not an abstract feature, but an appropriate response in a particular situation in a certain place and time, so that what is appropriate or possible in one 
situation, may not be so in another. Leadership is greatly influenced by the context, and its methods differ in war and peace, in crisis and in quiet times (Brown, 2014). Therefore, the historical, cultural, psychological, institutional, and political context in which the leader works is important. Brewster Smith has provided a very useful guide to the mutual relationship between the leader and his historical context, which influences the position of the leader, and is shaped and influenced by the leader in turn (Post, 2004).

Viewed within the context of Iraq and according to the complex of these four categories, leadership turns out to be emotional rather than rational, based on unconscious subordinate relationships with a bully follower who suffers from the pathological symptom of thinking he is the utmost best. This follower deliberately misleads his popular base, making it unable to distinguish between what is right and what is wrong, or what is good and what is bad.

Leadership in Iraq is not based so much in charisma as in excessive paternalistic control. It does not realize that it is a function that has its conditions and requirements, a human responsibility that has its own rules and ethics. Alternatively, those who aspire to leadership see it as a right and entitlement, a monopoly and a privilege, but the leader does not heed his followers unless his interest are served and he does not feel their presence unless his own presence and continuity are endangered, nor does he realize their needs unless his own need increases.

According to this description, the correct concept of the state is lacking in the consciousness of the leaders. The state is not perceived as a service (functional) organization that fulfills the requirements of the public interest, but as an entity that frames the individual self-interest of the leader. On the other hand, the followers and the popular base have an incomplete conception of what the state is. In their consciousness, it is synonymous with the leader, who becomes inseparable from it. Thus, the state is a reflection of the image of the ruler, who reduces the state solely to his own persona. 


\section{Rebuilding the State in the Context of IraQ}

According to Fukuyama (2004), state-building means creating new government institutions and strengthening existing ones. Fukuyama argues that state-building involves two different types of activities: reconstruction, which means restoring wartorn countries or devastated societies to their pre-conflict status, and development, which he sees as the creation of new institutions and the promotion of sustainable economic growth. Similarly, Paris and Sisk (2007) define the rebuilding of the state as "building effective and legitimate governmental institutions to create the necessary conditions for achieving stable peace and human development". Many opinions in several disciplines, such as developmental, humanitarian, political, and defense, support the centrality of state institutions in postwar peacebuilding.

However, Call (2008) argues that state-building can undermine peace while emphasizing that strong state institutions remain essential to promote peace. Call identifies three critical functions for peacebuilding by the state and highlights the complex relations between state legitimacy and its capacity and security in post-conflict societies, but he recognizes that states in general — because they represent certain social interestsare as much a problem for peace and development as a solution, especially when the state acts on behalf of a few people for their benefit. Concerning development, states may interfere with domestic initiatives, restrict markets, and provide services when this means obtaining resources from the citizens, and they may also become an important cause of war when they mistreat or frighten the population, or persecute and discriminate against one or more ethnic or religious groups.

Contrary to these views, which determine the process of building or rebuilding the state based on soft foundations, Dobbins (2008) and his colleagues add a hard dimension to the state-building process by defining it: "The use of armed force after a period of conflict or war to build a stable peace and a sustainable democratic system". Whether the process has soft or hard dimensions or combines the two, the element of time plays a big role; therefore, it is important to define the state-building agenda with a clear timetable, keeping in mind that each state-building case must follow a different path, depending on the reality of a given society (Ogun \& Aslan, 2013). 
Besides, the process of state-building involves general components, which are identified and enumerated in Table 1:

Table 1. General Components of the State-Building/Rebuilding Process

\begin{tabular}{|c|c|c|c|}
\hline $\begin{array}{l}\text { Constitutional } \\
\text { and institutional } \\
\text { dimension }\end{array}$ & $\begin{array}{l}\text { Military and } \\
\text { security dimension }\end{array}$ & $\begin{array}{l}\text { Economic } \\
\text { dimension }\end{array}$ & Value dimension \\
\hline $\begin{array}{l}\text { Rebuilding } \\
\text { constitutional, } \\
\text { legal, and } \\
\text { institutional } \\
\text { structures and } \\
\text { frameworks } \\
\text { (building a } \\
\text { democratic } \\
\text { political system, } \\
\text { a constitution, } \\
\text { enacting of } \\
\text { party laws, and } \\
\text { elections). }\end{array}$ & $\begin{array}{l}\text { Building a national } \\
\text { army and police } \\
\text { force that transcends } \\
\text { religious, ethnic, and } \\
\text { regional divisions } \\
\text { within society } \\
\text { and eliminating } \\
\text { corruption within } \\
\text { them. }\end{array}$ & $\begin{array}{l}\text { Laying the } \\
\text { foundations for } \\
\text { economic growth } \\
\text { through a form } \\
\text { of development } \\
\text { that provides } \\
\text { the necessary } \\
\text { foundations. }\end{array}$ & $\begin{array}{l}\text { A set of values and } \\
\text { principles that must govern } \\
\text { state-building policies, } \\
\text { and must be cultivated } \\
\text { as fundamental values in } \\
\text { the Constitution and new } \\
\text { laws, or as a philosophy } \\
\text { governing the functioning } \\
\text { of these institutions. } \\
\text { These values include the } \\
\text { protection of fundamental } \\
\text { rights, the rule of law, and } \\
\text { peace, which includes the } \\
\text { disarmament of conflicting } \\
\text { parties, and the peaceful } \\
\text { settlement of internal } \\
\text { conflicts. }\end{array}$ \\
\hline
\end{tabular}

\begin{tabular}{lll}
\hline $\begin{array}{l}\text { Achieve national } \\
\text { reconciliation, } \\
\text { enforce the rule of } \\
\text { law, and eradicate } \\
\text { corruption. }\end{array}$ & $\begin{array}{l}\text { Eliminate the } \\
\text { underlying structural } \\
\text { causes of violence } \\
\text { within society. }\end{array}$ & $\begin{array}{l}\text { The existence of } \\
\text { a project for the } \\
\text { reconstruction } \\
\text { of economic } \\
\text { institutions and } \\
\text { infrastructure. }\end{array}$ \\
\hline & $\begin{array}{l}\text { Eliminate militias, } \\
\text { and promote the } \\
\text { implementation of } \\
\text { economic and social } \\
\text { programs to contain } \\
\text { and integrate the } \\
\text { elements and leaders } \\
\text { of these militias. }\end{array}$ & $\begin{array}{l}\text { Work to reduce } \\
\text { the level of } \\
\text { dependence on } \\
\text { foreign economic } \\
\text { assistance. }\end{array}$ \\
\hline
\end{tabular}


The Organization for Economic Co-operation and Development (OECD) has identified five dimensions for the state-building/rebuilding process, as shown in Table 2:

Table 2. The Five Dimensions of the State-building Process as Defined by the Organization for Economic Co-operation and Development (OECD)

\begin{tabular}{lllll}
\hline $\begin{array}{l}\text { Political } \\
\text { processes }\end{array}$ & $\begin{array}{l}\text { State / Society } \\
\text { Relations }\end{array}$ & $\begin{array}{l}\text { State } \\
\text { legitimacy }\end{array}$ & Social expectations & $\begin{array}{l}\text { Ability to } \\
\text { perform state } \\
\text { functions }\end{array}$ \\
\hline Elections & $\begin{array}{l}\text { General } \\
\text { Dialogue }\end{array}$ & $\begin{array}{l}\text { Divergent } \\
\text { causes of } \\
\text { loyalty }\end{array}$ & $\begin{array}{l}\text { What groups expect } \\
\text { from the state }\end{array}$ & $\begin{array}{l}\text { Rule of law and } \\
\text { access to justice }\end{array}$ \\
\hline $\begin{array}{l}\text { Parliamentary } \\
\text { processes }\end{array}$ & $\begin{array}{l}\text { Society's } \\
\text { contribution to } \\
\text { policy making }\end{array}$ & & Taxation \\
\hline Decentralization & & & $\begin{array}{l}\text { Delivery of } \\
\text { services }\end{array}$ \\
\hline & & & $\begin{array}{l}\text { Economic and } \\
\text { environmental } \\
\text { management }\end{array}$ \\
\hline
\end{tabular}

Source: Ogun and Aslan (2013).

Haldén (2010, pp. 525-526) adds external factors as an important dimension of the state-building/rebuilding process and focuses on the need to take into account the systemic context. Since the process faces greater challenges than mentioned in many documents and strategic literature, which makes the possibility of rebuilding by supporting internal processes and institutions alone insufficient, Haldén presents three important factors representing external conditions for the state-building/ rebuilding process. Furthermore, Haldén considers it is a top priority in contemporary international security to increase regional security and prevent threats that may have global effects, such as terrorism, organized crime, and the proliferation of weapons of mass destruction. The factors presented by Haldén are: first, the establishment of effective states, which requires regional acceptance of the state-building process; second, sustainable regional security at and within countries, which requires the 
establishment of effective state structures across the region; third, an effective interstate security system, which requires efficient systems of states.

Lake (2010, pp. 257-258) presents the role of the external factor by extrapolating the experience of the United States of America and its contributions to the state-building process. The United States followed three models of state-building beginning in the 1890 s, and each of these models was built according to a different political theory. The first model, developed and used until the end of the Cold War, was based on the theory of realpolitik. This model emphasized the building of loyal and stable states, and it prioritized us geopolitical and economic interests over the interests of the local population. The second model originated in the United States' attempts to build a new world order after 1990. At this stage, liberalism prevailed; this model was characterized by a major shift from seeking loyalty to building legitimate states. The United States has tried to build broad public support for emerging countries by establishing democratic institutions and leading economic reforms. The third model, put to the test in Afghanistan and Iraq in the third millennium, seeks to build legitimacy for new states by providing security and basic public services to their populations. Although the goals of the second model continue to be embraced, democracy and economic reform have fallen off the list of priorities for many reasons explained by Lake in the course of his study. This model is based on the social contract theory, and its basic principle is that legitimacy comes from providing the basic needs of citizens effectively.

From the external factor perspective, some see "state-building" as a very limited set of situations in which external actors have assumed some or all aspects of sovereignty, and often refer to this as international (local) regional administration and include among the most prominent cases Kosovo, East Timor, and Iraq; because of the unusual nature of these cases, as Chesterman (2011, p. 3) explains, a broader definition has been adopted by many commentators and practitioners, so as to encompass a wide range of efforts to support state institutions with a greater focus on the role that national actors must play. The Secretary-General's report on peacebuilding in June 2009 provides an example, as the report repeatedly stresses that the primary responsibility lies with national actors, although the "international community" can play a crucial role. 
Chesterman et al. (2004, pp. i-ii) concur with this view, arguing that states cannot be made to run from the outside and that international assistance is necessary but never enough to establish legitimate and sustainable institutions, since the main actors in these cases are always local. However, this is no excuse for inaction conducive to minimizing the humanitarian consequences of the inability of the state to care for its vulnerable population, and international actors may play an important role by facilitating local processes, providing resources, and creating the opportunity for local actors to establish legitimate and sustainable governance, as well as by initiating talks that will define and consolidate the political entity and mediate among the relevant parties to achieve their vision of a good life with responsive, strong, and flexible institutions. However, the key question facing external actors is whether they should engage in top-down or bottom-up policies: to foster institutions and leaders or to strengthen an effective civil society in the hope that this will lead to the development of enlightened leadership in the long run. Chesterman and his colleagues conclude that state-building works best when people gather behind an enlightened leader, but very little will it succeed if they gather behind someone who is not.

According to the state-building perspective, Iraq suffered from many failures and witnessed many transformations and developments resulting from a combination of soft and hard forces. Since the beginning of the 1980s, Iraq has undergone periods of institutional collapse at all levels and a decline in values involving many joints in society. The first Gulf War of 1980 opened these phases and the economic sanctions and isolation of Iraq in the 1990s increased it. Then the third millennium fired a bullet of mercy and ended every milestone of the real state: "Everything collapsed".

The third Gulf War of 2003 represented a double-point, both beginning and end. On the one hand, an existing, albeit restricted, state came to an end and set the stage for building a new faltering state that inherited all the failures of its predecessor while worsening others. Although the new state rooted the negative elements of the previous state and has surpassed its positive elements, the later have been neglected and not taken advantage of. It has deepened the fault lines at the internal level and increased fear, insecurity, and threats in the regional and international contexts. All of this has made the rebuilding process easy and difficult at the same time, and the construction process easy but sterile, because it lacks exceptional leadership that 
simultaneously understands the true meaning of leadership and the state, and goes beyond the negative legacy of both.

While the pre-occupation state was inclusive, monolithic, and absolute, monopolizing truth and glorifying individualism and authoritarianism, the post-occupation state has moved from stumbling in its unity to deepening its crisis over its present and future, especially in light of the rapid rise of dismantling and fragmenting factors. This is a crisis manifested by many signs and represented by the inability of the post-occupation State to achieve independent and sustainable development in all its aspects: political, economic, social, cultural, legal, educational, sanitary, and environmental. Additionally, there has been no progress in the field of social and class justice, and social inequalities have increased dramatically, as well as the proportion of poorer groups. In the political field, the manifestations of the crisis were intensified by the reduction of the circle of political and popular participation and by failing at national reconciliation, despite the many projects that were attempted. The most serious manifestation of the crisis is evinced in the vertical fragmentation experienced by the state since the occupation, which warns (Shabban, 2016, pp. 160-161) of serious repercussions for the political process.

According to the above mentioned, Bouillon (2012, pp. 282-283) argues that the lessons of history must be fully appreciated when considering the long-term future of the Iraqi state, and he supports this claim with four main arguments. First, the central problem in Iraq, when speaking from a historical perspective, is the fragility of the state or the failure to unify the state successfully. Second, if state fragility is the problem, and if its historical importance is sufficiently taken into account, the solution to state-building should not be conceived in the sense of political rebuilding, but in the sense of building a sustainable Iraqi state from the bottom up. Third, state-building is itself a long-term task, and only Iraqis themselves can move forward with it. Fourth, external actors can only support this endeavor by encouraging the negotiation of a national social contract through an Iraqi-led process.

With the realistic outlook of these arguments, especially the third and fourth, where does leadership stand in the building of the Iraqi state? 


\section{THE ROLE OF LEADERSHIP IN REBUILDING THE STATE}

Leadership is a key pillar, and perhaps the most important pillar, in the process of rebuilding the state; it also represents the main engine that helps the state to emerge from failure and collapse. Its importance stems from the absence of state institutions in the early stages of the rebuilding process, which makes the impact of leadership clear and decisive in the political process and even in the entire political system, and so its impact extends to all other subsystems beyond this system. The rational vision behind political leadership has specific features and it determines the priorities of the society and the optimal utilization of state resources. It also determines the most appropriate form of governance for society, but, in turn, faces many problems stemming from the overall context in which it operates. Therefore, the process of rebuilding the state in its essence is a reflection of the continuous interaction between the prevailing ideology on vital issues that concern citizens which reflects to some extent the level of rational development of the members of that society — and its material and productive reality and economic structure, as well as political leadership, which is the catalyst factor for this interaction. This process of interaction forms the general framework that determines the evolution of the process of state-building and its various objectives; consequently, the construction process has two aspects, the first relates to leadership itself, its role, and characteristics, and the second relates to the state and its ability to perform its functions (Hussain, 2015, pp. 11-14).

The correlation between these two sides can be thought as an important equation: the leadership has a role in the development of the ability of the state to perform its functions in the context of the rebuilding state process. And the question here is: has this equation worked properly in the process of rebuilding the state in Iraq?

As mentioned above, the leadership in Iraq is not perceived as a function that has its conditions and requirements, nor is the state a functional organizational institution that fulfills the requirements of the public interest. The dimension of values, which covers all dimensions, was absent from the state-building process, and the values and principles governing this structure were not established. 
The dimension of values is closely linked to collective action in the context of statebuilding, where it is necessary to shift power from the individual to the group. The uncertainty associated with crises is related to the idea that leadership is not a science but an art: the art of engaging society in the face of complex collective problems and feeding the collective identity by recognizing the importance of building social capital. Leadership in Iraq has moved far from this logic, becoming more authoritarian and individualistic than participatory, although society bears a large part of the responsibility, given that power is a relationship, and the change is based on the relationship between the leader and the followers: followers, not just leaders, develop or destroy change strategies, since institutions are systems, not machines (Grint, p. 2010).

Thus, the group has been marginalized from the process of rebuilding the state in Iraq, and leaders contributed to prolonging the conflict and generating crises because they knew that the end of the conflict weakens or reduces the need for leadership. As long as crises persist, they reinforce the need for leadership, so leadership depends on the persistence of the crisis context.

Therefore, the leadership did not contribute to strengthening the functions of the state and building its institutional structure, which collapsed in 2003. Quite the contrary, the leadership has produced a political crisis that has escalated into a conflict between opposing patterns of internal actors, as a reflection of the different orientations, objectives, and strategic and tactical plans held by the different parties. Moreover, the weakness of the leadership and the fragility of its role opened the door to make Iraq a center for regional and international strategic problems (Ali, 2009, pp. 72-73), which had opposite negative effect on the leadership in Iraq and its outputs. The crises and conflicts generated by the leadership can be summarized in three issues that stood against the attempts to rebuild the state in Iraq:

\section{Conflict of identities}

After the change of regime, Iraq entered into an identity crisis. The absence of identity within the overall framework influenced the strengthening of narrow frameworks 
and affiliations in various forms (sectarian, religious, ethnic, tribal, regional), which has hampered the emergence of a coherent national elite who owns the state building project. In the absence of confidence between these components, the rise of forces aimed at building a state based on factional identities, rather than on the identity of citizenship and competence, has been facilitated. The state became subject to quotas in power-sharing, which lead to be a state of sects rather than state over sects (Qati, 2010, p. 357).

Therefore, it can be said that the social components have failed to be a harmonious nation that comprehends the concept of the modern state. Analysts have mentioned that main reason Iraq has been drowned by narrow affiliations throughout its history as a central state is that all Iraqi rulers - from King Faisal I to Abdul Salam Aref, Saddam Hussein, and post-2003 leaders — had no vision to develop a comprehensive idea of a multi-ethnic Iraq far from narrow limitations, so none of them seriously sought to build Iraq's composite identity from persistent ethnic, sectarian, and tribal identities (Khan \& Kirmanj, 2015, p. 6).

The absence of the state and the fragility of power has stemmed from a constitutional vacuum and the absence of military, security, and other state institutions. However, the modernity of the political experience under democratic rule has produced a fertile ground for ongoing crises due to incomplete legislation. Besides, it is a weak and ambiguous document that requires constant interpretation by the Federal Supreme Court, which was influenced by the policies which support the power (Ottaway \& Kaysi, 2012). The fragility of the Constitution and its lack of interest in building a state at the level of regional relations and provincial councils and local governments and how to manage them, created a structural problem for the political system which makes it vulnerable to collapse. The remnants of the previous state, the dilemma of the Constitution, the improper policies for building a new state, the political forces who proclaimed the truth of the Constitution thus produced multiple problems based on sectarian understanding, all of these were key sources of ongoing conflicts (Ottaway and Kaysi, 2012). 


\section{Political wills in conflict}

Suffering from a structural crisis, the Iraqi political system formed in the presence of incompatible coalitions that have suffered from the absence of clear ideological and political programs; their aim has been to build state institutions for the benefit of narrow-minded elites to obtain privileges that stand against their commitments to society. This has reinforced the approach of political wills based on the intensity of their speeches and political orientations in dealing with one another. The absence of a specific and clear form for this state and its strategies constituted an obstacle to the process of rebuilding it (Qati, 2010, p. 359).

The Iraqi political reality has produced non-democratic leaders in their behavior and approaches to resolving the ongoing crises that affect the state. This confirms the fact that they are a political elite which adheres to consensual democracy and power-sharing, but which has caused the monopoly of power and the disagreement among state institutions to steadily increase, and so have generated the need for power-sharing and consensus in the constitutional fabric of the political structure (Khan \& Kirmanj, 2015, p. 24).

This has produced the absence of the idea of the modern state and its requirements in the mentality of politicians and political parties in Iraq after 2003, with many leaders conceiving power according to the concept of parental authority and practicing it without notion of the concept and meaning of functional authority. Observers of the Iraqi scene can diagnose the emergence of multiple leaders with categorical followers, which has traditionally pushed society towards parental authority and a tendency to authoritarianism at various levels and institutions, to the point that the collective administrative culture went absent and the benefits were mixed between the political and the personal interests; the service benefits declined at all levels, and personality emerged at the expense of institutions, as the higher administrative segments in the public sectors are still neglected by the effects of nepotism and the exploitation of influence. They have brought leadership norms from society into institution instead of creating an institutional leadership system that replicates itself within the framework of the modern state, in which case the state gains stronger institutional and administrative capacities. 
Moreover, the promotion of tribalism brought the state into a dialectical relationship in favor of the clan at the expense of the state entity. The state weakened as tribes became a social incubator for the Iraqi political parties and became an influential base in the electoral process. Tribes became one of the most influential social forces in creating political positions and gaining electoral votes, without taking into account the dangers of tribal nepotism and cronyism and their negative impact on the work and performance of institutions; this was aggravated by the weak role of political leaders in building civil state properly and the growing success of clan authorities at applying tribal customary law in resolving many conflicts as an alternative to civil laws. Moreover, government forces resorted to the use of clans, and a good example here is the formation of tribal support councils, which were directly linked to the office of the Prime Minister and turned into the so-called "Tribal Crowd". All this was reflected in the fact that the political transformation taking place in Iraq was capable of establishing a civil state based on the concepts of citizenship, equality, and social justice, instead of weak state organs and the fluctuation of the application of its laws. It can be argued with Fukuyama (2011) that while the clan is a reality in contemporary life and remains one of the greatest constants of political development, the struggle will continue "in the 21 st century to replace forms of tribal politics with more objective and non-personal political relations".

There is also the lack of clarity and stability of the economic system and fiscal policy of the state. Since 2003 the economy of Iraq has remained within a rentier framework, which is the source of crises, because it leads to weakening the role of the individual and society in being an effective tool that supports the leadership in the state-building process, in addition to intensifying the political conflict for power, as there are no other possible outlets to rely on for the expansion and development of the Iraqi economy.

\section{The conflict of regional axes}

Iraq has been plunged into the conflict of regional axes, with dealings that range between the negative and positive. The conflict has forced changes into the Iraqi political system, as well as its intervention in supporting some political leaders as 
dictated by their interests in Iraq, which is reflected on the features of Iraq's future policy and state-building (Qati, 2010, p. 360).

The dilemma faced by many leaders, as Chesterman (2011, p. 10) argues, is how to keep the external axes satisfied and ensure the flow of aid and at the same time create their own democratic credentials or their local political power.

The immaturity of democratic practice has led to the use of democracy as a mechanism to gain power only, while retaining anti-democratic values such as totalitarian ideas and the intolerance of different ones. This has been reflected in the difficulty of political actors to realize the nature of the challenges that face the democratic experience, and this has generated more crises and problems that give the major world powers the argument to interfere in the country's affairs, on the basis that the crises of weak, failed, and troubled countries today pose a serious security threat to the powerful and rich countries.

\section{Conclusion}

Leadership can be described as the ability to use the power resources to manage crises in society and the state, or to find solutions to problems faced by that community or state, as well as the ability to organize relationships and manage resources. As leadership is the ability to steer towards specific strategic objectives to build the state, the absence of objectives from the leadership is enough to lead the leadership into a real crisis, especially with the absence of tools and methods to exercise it.

The leadership crisis in Iraq is embodied in a set of sustainable crises that need radical solutions, based on deliberate long-term strategic plans, especially in the absence of constructive visions and the prevalence of self-interest. It is also embodied in the impact of social reality on leadership practices, which reinforces the predominance of narrow sub-identities at the expense of a collective identity which undermines statebuilding and favors the building and consolidating clan components. 
The fact that the Iraqi leadership did not possess a culture of state-building after 2003 was reflected naturally on the slow process of political development to complete institution-building, and the prevalence of racial, sectarian and national social complexities over the Iraqi mentality, instead of the issue of state-building and its economic, developmental, and political system. This demonstrated to the communities and clans that it is difficult to reach a single political decision in the direction of construction, as long as such a reality could produce conflict leaders rather than constructive leaders, especially taking into account that Iraq is located in a region that is experiencing axes conflicts, and that most of its leaders are imbricated in those axes to obtain personal gains and interests.

Moreover, the continuation of crises in the Iraqi political reality confirms the existence of a cultural crisis in the production of conscious and democratic leaders and a tendency to produce leaders with religious, tribal, and often nationalist charisma. Thus, the instability of Iraqi political reality indicates the absence of effective leadership in the democratic experience in Iraq.

\section{REFERENCES}

Ali, I. A. (2009). usA Strategy and Management of Political Wills Conflict in Iraq. International Studies, 41, 69-94.

Bouillon, M. E. (2012). Iraq's State-building Enterprise: State Fragility, State Failure and a New Social Contract. International Journal of Contemporary Iraqi Studies, 6(3), 281-297.

Brown, A. (2014). The Myth of the Strong Leader: Political Leadership in the Modern Age. New York: Basic Books.

Call, C.T. (2008). Building States to Build Peace? A Critical Analysis. Journal of Peacebuilding and Development, 4(2), 60-74. 
Chesterman, S. (2011). State-Building, the Social Contract, and the Death of God. New York University Public Law and Legal Theory Working Papers. 253. Retrieved from https://lsr. nellco.org/nyu_plltwp/253

Chesterman, S., Ignatieff, M. \& Thakur, R. (2004). Making States Work: From State Failure to State-Building. New York: International Peace Academy.

Dobbins, J. et al. (2003). America's Role in Nation-Building: from Germany to Iraq. Santa Monica, CA: RAND Corporation.

Dobbins, J. et al. (2008). After the War: Nation-Building from FDR to George W. Bush. Santa Monica, CA: RAND Corporation. Retrieved from https:/www.rand.org/content/dam/ rand/pubs/monographs/2008/RAND_MG716.pdf

Farhat, M. F. (2015). Occupation and State Rebuilding: Comparative Case Studies of Japan, Afghanistan, and Iraq. Beirut: Arab Unity Studies Center.

Fukuyama, F. (2004). State Building: Governance and World Order in the Twenty-First Century. usa: Cornell University Press.

Fukuyama, F. (2011). The Origins of Political Order: From Prehuman Times to the French Revolution. Farrar, Straus \& Giroux.

Grint, K. (2010). Leadership: A Very Short Introduction. Oxford: Oxford University Press.

Haldén, P. (2010). Systems-Building before State-Building: on the Systemic Preconditions of State-Building. Conflict, Security \& Development, 10(4), 519-545.

Hussain, A. S. (2015). The Role of Political Leadership in the Rebuilding of State: Russia under Putin. Beirut: Arab Unity Studies Center.

Khan, S. \& Kirmanj, S. (2015). Engineering Confederalism for Iraq. National Identities, 17(4), 371-385. DOI: 10.1080/14608944.2015.1066322 
Lake, D. (2010). The Practice and Theory of us Statebuilding. Journal of Intervention and Statebuilding, 4(3), 257-284.

Mottahedeh, R. (1980). Loyalty and Leadership in an Early Islamic Society. Princeton N.J.: Princeton University Press.

Ogun, M. N. \& Aslan, M. (2013). Theory and Practice of State Building in the Middle East: A Constitutional Perspective on Iraq and Afghanistan. Journal of Applied Security Research, 8(3), 374-403.

Ottaway, M. \& Kaysi, D. (2012). The State of Iraq. Washington, DC: Carnegie Endowment for International Peace. Retrieved from https://carnegieendowment.org/2012/02/08/ state-of-iraq-pub-47127

Paris, R. \& Sisk, T. D. (2007). Managing Contradictions: The Inherent Dilemmas of Postwar Statebuilding. International Peace Academy. Retrieved from: https://www. jointpeacefund.org/files/documents/roland_paris_-_statebuilding_overview_paper.pdf

Post, J. (2004). Leaders and Their Followers in a Dangerous World. UsA: Cornell University Press.

Qati, S. K. (2010). Challenges of Iraqi Modern State Building. Political Science, 41, 356-361.

Shabban, H. (2016). The current Iraqi crisis: Sectarianism, regionalism and the state. International Journal of Contemporary Iraqi Studies, 10(1\&2), 153-174. 